\title{
Immigration and Swiss House Prices
}

\author{
Kathrin Degen a and Andreas M. Fischer ${ }^{b}$
}

JEL-Classification: F22, J61, R21

Keywords: immigration, housing prices

\section{SUMMARY}

This study examines the behavior of Swiss house prices in relation to immigration flows for 85 regions from 2001 to 2006 . The results show that the nexus between immigration and house prices holds even in an environment of low house price inflation and modest immigration flows. An immigration inflow equal to $1 \%$ of an area's population is coincident with an increase in prices for single-family homes of about $2.7 \%$, a result consistent with previous studies. The overall immigration effect for single-family houses captures almost two-thirds of the total price increase.

a State Secretariat for Economic Affairs SECO, Holzikofenweg 36, CH-3003 Bern Email: katharina.degen@seco.admin.ch. This paper was written when Kathrin Degen was with the Swiss National Bank. The views and opinions expressed in this paper are solely those of the authors and do not necessarily reflect the positions of the Swiss National Bank or the State Secretariat of Economic Affairs. The authors would like to thank Barthélémy Bonadio, Martin Brown, Tommaso Frattini, Sarah Lein, Albert Saiz, Steven Stillman, and an anonymous referee for their valuable comments. The authors also benefited from discussions with Urs Hausmann and Dieter Marmet from Wüest \& Partner and numerous students from Swiss Universities. Data and code are available from the authors. The authors acknowledge use of the dataset described in Mack and Martinez-Garcia (2011).

b Swiss National Bank, P. O. Box, CH-8022 Zurich, Switzerland Email: andreas.fischer@snb.ch. 


\section{Introduction}

Recent evidence from country studies on house prices suggests that the effect of immigration on local house prices is a global phenomenon. SAIZ (2007) estimates that an immigrant inflow equal to $1 \%$ of a city's population results in a $2 \%$ increase in house prices for U.S. cities. GonZalez and Ortega (2013) show that the price effect through immigration is higher for the Spanish housing market. AKbARi and Aydede (2012) instead find muted immigration effects for the Canadian housing market. STILLMAN and MARÉ (2008) uncover separate results for migrant groups. They find that the inflows of returning New Zealanders are related to rising house prices but that inflows of new foreign immigrants are not. A striking feature of these spatial correlations - the correlation between house prices and immigration across local markets - is that they coincide with episodes of high house price inflation and pronounced immigration flows at the national level. Gonzalez and Ortega (2013), for example, consider a boom episode where Spanish house prices grew annually by $17.5 \%$ and the foreign-born share in the working population increased from 2 to $16 \%$ between 1998 and 2008. Similarly, SAIZ (2007) examines a 15-year episode where prices for new singlefamily homes grew annually by $6.3 \%$ and the 10 largest American immigrant cities recorded levels of new legal immigration of $13 \%$ of the initial population. ${ }^{1}$ The effect of immigration for periods of low house price inflation has not been previously examined.

The objective of this paper is to show that the nexus between house prices and immigration holds also for episodes of low house price inflation and modest immigration inflows. These market features may suggest that the demand induced pressures from immigration are weaker in an environment of low house price inflation. More specifically, we examine the behavior of Swiss house prices in relation to immigration flows for 85 regions in the pre-financial crisis period between 2001 and 2006. During this period, the population-weighted average price for single-family homes grew annually by $1.5 \%$ and the immigration inflow to Switzerland was consistent with the European average of around 3 immigrants per 1000 inhabitants.

The paper addresses the issue of possible endogeneity of immigration with respect to omitted factors that simultaneously affect local house prices and immigration by employing an instrumental variables strategy which is based on the

1 The figure 6.3\% applies from 1983 to 1997 for new single-family homes using the index from the U.S. Department of Housing and Development. 
pattern of immigrant's location choices in earlier periods. The idea of this instrumentation strategy is to isolate variation in immigration which does not operate through "pull factors" at the destination country. The so called "shift share" or "supply push" instrument was first developed by CARD (2001) and exploits the settlement patterns of previous immigrants to identify the causal effect of immigration on local employment. It has been widely applied in the context of labor economics (Basten and Siegenthaler, 2013; Borjas, 2003, 2006; Glitz, 2012; Orrenius and Zavodny, 2007), innovation (Hunt and GauthIER-Loiselle, 2010), money demand (Fischer, 2014), and housing prices or rents respectively (Saiz, 2007; Fischer, 2012; Gonzalez and Ortega, 2013; ACCetturo et al., 2014).

Conditioning on a set of local variables, our estimates find that an immigration inflow equal to $1 \%$ of a region's population is coincident with an increase in prices of about $2.7 \%$ for single-family homes and of $3.5 \%$ for multifamily homes respectively. The average immigration effect for single-family houses explains almost two-thirds of the total price increase. While international studies, for example by Saiz (2007) and Gonzalez and Ortega (2013), tend to focus on house prices of single-family homes, the results show that the effect of immigration on multi-family homes and condominiums are also important.

There is a rapidly growing literature on the Swiss housing and mortgage market. Borowiecki (2012), Drechsel (2015), and Steiner (2010) use a time series approach in order to make statements about housing prices over the business cycle. BAsten and Косн (2015a) examine the post-crisis period to understand whether financial regulation, in particular cyclical capital buffers, affect mortgage lending. Guin and Brown (2015) use a novel dataset on recent mortgage applications to quantify the exposure of borrowers to potential interest rate, income and house price risks and analyze how households' interest rate expectations, house-price developments and individual risk aversion affect mortgage contract choice. These studies however do not investigate the effect of immigration on house prices directly.

Studies by Basten and Koch (2015b) and Fischer (2012) are closest to ours. Each examine the causal effects of immigration on house prices with the use of the CARD (2001) "shift share" instrument. BASTEN and КосH (2015b) examine the effect of local immigration on house prices as part of the first stage of their two-step process to identify house price effects on mortgage demand. Their identification strategy is based on isolating the exogenous variation in Swiss house prices due to exogenous shocks to immigrant inflows to identify the causal effect of house prices on mortgage demand. The study finds strong evidence for a positive first-stage effect of the exogenous component of immigration on house prices. 
Their first-stage result suggests a strong link between immigration and house prices in our post-sample period between 2008 and 2013, when house price inflation was substantially higher than in the sample period between 2001 and $2006 .{ }^{2}$ Fischer (2012) examines the effect of immigrant language barriers for Swiss house prices between 2001 and 2006. He tests the implicit assumption of SAIZ (2007) that immigrants are less price sensitive to house prices because of their demand for local amenities. Fischer (2012) uses the same data base as this study and finds that house prices for single-family homes respond strongly in regional areas where there is a strong influx of immigrants that do not share a common language with Switzerland's main national languages. That study however does not consider the effect on prices for multi-family homes and condominiums.

The paper is organized as follows. Section 2 discusses the specific features of the Swiss housing market. Section 3 discusses the data and descriptive statistics. Section 4 presents the empirical methodology. Section 5 documents the empirical results. Section 6 concludes.

\section{The Swiss Housing Market}

In this section, we outline the main distinguishing features of the Swiss housing market and argue that our results are primarily explained by demand shocks in tight local markets.

First, house price inflation in Switzerland is low by international standards in the pre-financial crisis period. Figure 1 lists the annual real increase in house prices for 18 OECD countries averaged over the years 1975 to 2007 for the prefinancial crisis period and from 2008 to 2015 for the post-crisis period. The historical record shows that the average real price increase for Swiss housing is $0.3 \%$ prior to the financial crisis. This figure is the third lowest among the advanced countries and is ten times lower than the returns for U.S. homes examined in

2 In terms of methodology, HäCKI (2015) is closest to ours. She examines the post-sample period from 2009 to 2013 and finds that the immigration's effect on Swiss house prices to be weaker (i. e., between 1.5 and $1.6 \%$ for single-family homes) for a period of higher price house price inflation. While it is difficult to explain this result, her sample captures economic developments that are certainly more complex than our "pre-financial crisis" sample. Our sample is not forced to disentangle the effects of a zero interest rate environment, new financial regulation with a changing banking environment, and an investment environment with greater international risks that could impede the identification of the immigration effect on house prices. 


\section{Figure 1: Real House Price Growth}

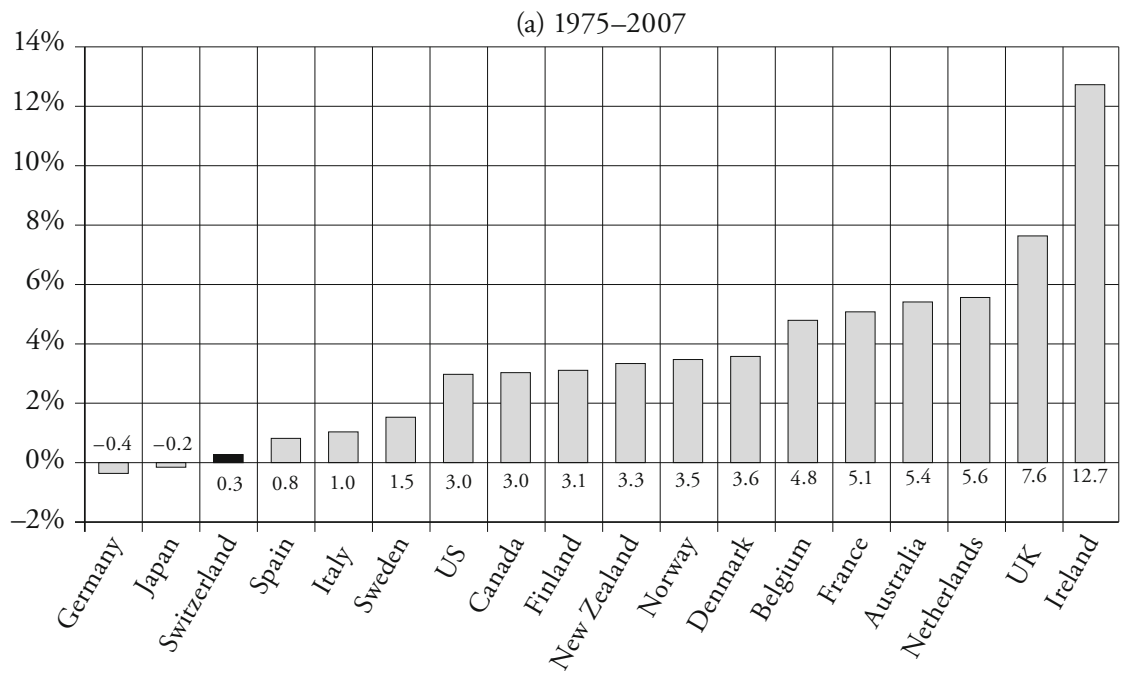

(b) $2008-2015$

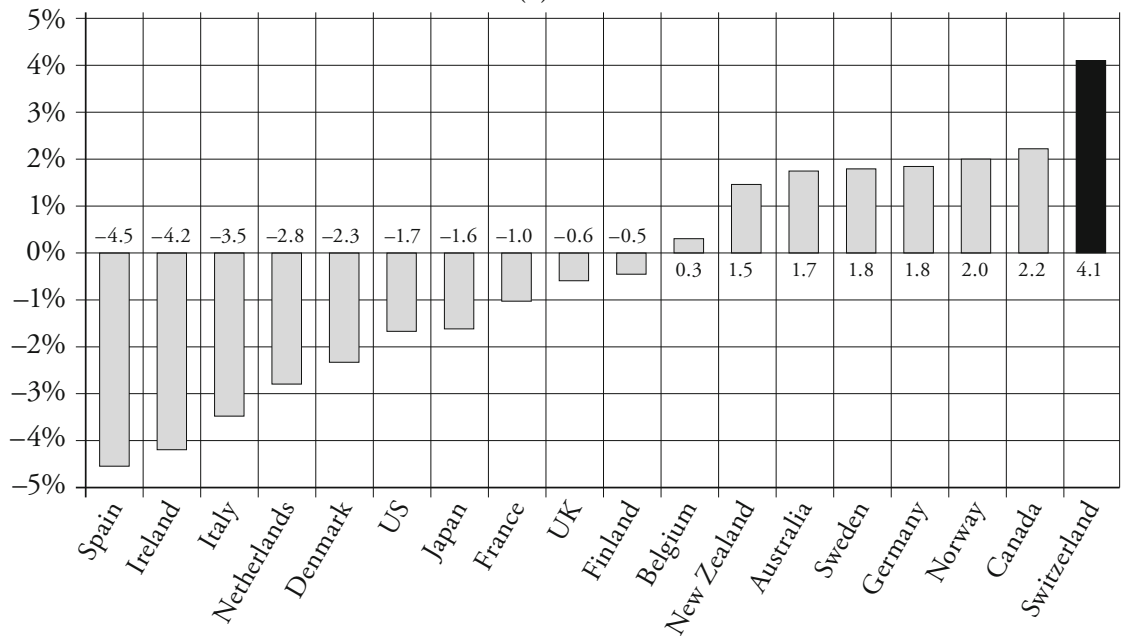

Notes: The figure shows the average annual real growth in house prices between 1975 and 2015. Subfigure 1(a) shows average annual growth in the period before the financial crisis of 2008, i.e., the period between 1975 and 2007, and subfigure 1(b) depicts the average growth in the post-crisis period between 2008 and 2015 for 18 OECD countries.

Source: Own calculations based on data from the International House Price Database (www.dallasfed.org/institute/houseprice) 
SAIZ (2007). ${ }^{3}$ In the period from 2008 to 2015 , house price inflation is considerably higher: With an average annual real growth of around $4.1 \%$, Switzerland ranks highest among the 18 OECD countries. However, even in the evaluation period between 2001 and 2006, which is marked by low average house price inflation, there is large regional variation. Table 1 shows that house price growth is significantly larger in regions with large immigrant inflows. Instead in regions with few new immigrants, house prices remained relatively stable.

Second, demand for owner occupancy is low in international comparisons (see Werczberger (1997)). The rates for home ownership in Canada (65.8\%, national census 2001), New Zealand (67.8\%, 2001), Spain (85.3\%, 2000), and the United States $(67.8 \%, 2000)$, countries examined in previous house pricel immigration studies, are twice that of Switzerland (35.5\%, 2000). Unlike in many other countries, the Swiss federal government does not actively promote home ownership. ${ }^{4}$ This signifies that in Switzerland the rental market plays an important role - this is especially true for new immigrants who are most likely to settle first in rental apartments. GRAF, JANS, and SAGER (2007), for example, show that home ownership is considerably lower for immigrants. While in 2006 one in two Swiss citizens live in their own home, this number drops to one in ten for newly arrived immigrants. ${ }^{5}$

There are several channels in which rental prices and real estate prices could be connected. One possible channel is low native displacement. In other words, local residents do not move away from their community when new immigrants arrive. This increase in housing demand for rental units could generate spillover effects into condominiums or single-family homes, if local residents seek alternative local housing accommodations. Another possible channel is that immigrant flows affect rental prices and this in turn affects house prices through the present value relationship of higher streams of future rents. ${ }^{6}$

3 WÜest \& Partner (2004) calculate international investment returns for housing, yielding similar results as in Figure 1.

4 In fact, taxes discourage owner-occupancy in Switzerland. Property is treated as an asset subject to wealth and income taxes for imputed rental income. Further, unlike other financial investments in Switzerland, housing is subject to capital gains taxes. Capital gains are taxed at the cantonal level with rates differing by duration of ownership.

5 This divide in home ownership between natives and immigrants exists also for other countries. Gobillon and Solignac (2016) show French home ownership is considerably lower for immigrants than for native residents. They emphasize the importance of credit frictions.

6 Unfortunately, we cannot directly distinguish these channels, because data on rental prices is not available at the MS-region level for the whole sample period. Future work that uses recent and longer time series should use both house price indexes and rental indexes. 
Figure 2: Rental versus Single-Family Home Prices

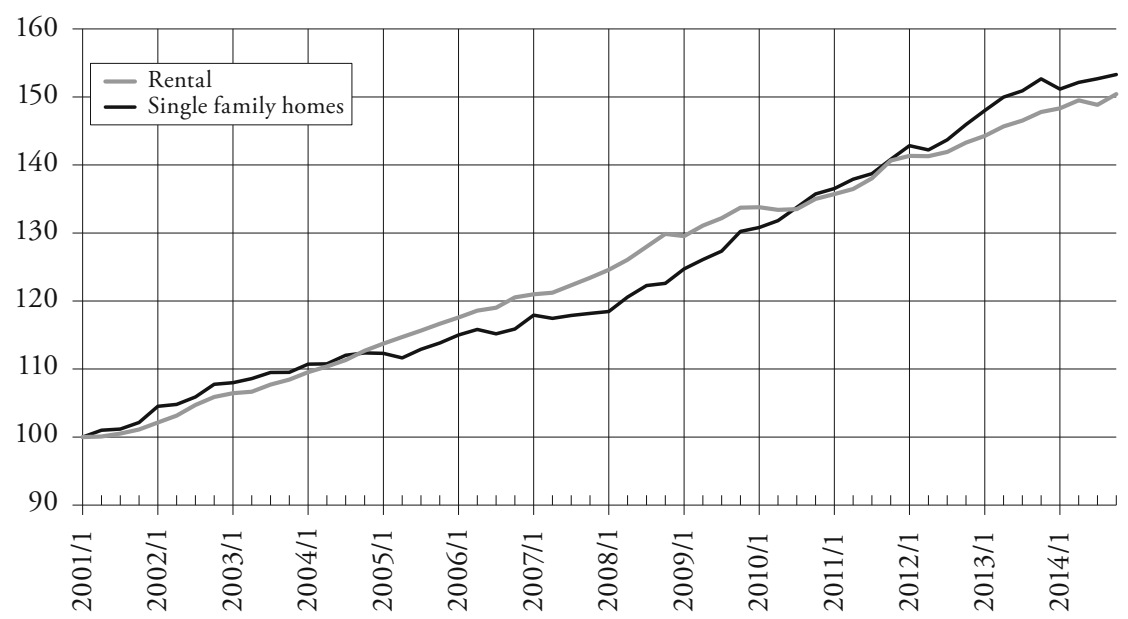

Notes: The figure shows the the rental price index and the single-family home price index from Wüest \& Partner for 2001 to 2014 for Switzerland as a whole. Both indexes are normalized to 100 in 2001Q1.

Source: Own calculations based on Wüest \& Partner price indexes.

Figure 2 shows quarterly levels of the Wüest \& Partner index for rents and single-family homes from 2001 to 2014 for Switzerland. Two observations are worth noting: First, the figure clearly shows the close connection between rents and housing prices. There is a clear upward trend in the price index for singlefamily homes and the rental index over the period from 2001 to 2014. Second, house prices show greater fluctuations than rents. House price grow slower than rents in the evaluation period between 2001 and 2006. By contrast, in line with Figure 1, house price growth exceeds rental growth in the post-crisis (and postsample) period. One possible explanation for the smoother evolution of rental prices compared to house prices are legislative constraints. Rent increases must be justified by the landlords' cost increases, see STALder (2003). As such, rent increases might not fully reflect market pressures.

Finally, the Swiss housing market is characterized by low vacancy and low turnover rates. For our period of investigation, the average vacancy rate, measured by the Swiss Federal Statistical Office, is $1.34 \%$ for Swiss rental units compared to $9.7 \%$ for U.S. rental units. The tightness of the Swiss housing market is also reflected in low occupancy turnover rates. Wüest \& Partner estimate the average 
stay to be 5 to 6 years for rental units, 12 to 14 years for condominiums, and 20 years for single-family homes. ${ }^{7}$ Tightness in local markets thus might explain why also relatively modest immigrant flows have a measurable effect on housing prices. Immigrant flows can be interpreted as local demand shocks that - given that the supply is fixed in the short run - drive up housing prices.

\section{Data and Descriptive Statistics}

We analyze an annual sample from 2001 to 2006 - a period prior to the financial crisis which is marked by low house price inflation - spanning 85 regions that had a residential population of at least 25000 inhabitants in 2001. The term "region" refers to the 106 MS ("mobilité spatiale") regions, which are characterized by some degree of spatial homogeneity and act as local labor markets. We excluded 21 regions with a population fewer than 25000 in 2001, because these are primarily mountainous regions. The excluded regions are largely unaffected by immigration flows for our sample period and do not contribute to the spatial heterogeneity that we exploit to identify the links between immigration and real estate prices. ${ }^{8}$ The examined 85 regions capture $96 \%$ of the Swiss residential population.

Data on house prices are from the Informations- und Ausbildungszentrum für Immobilien (IAZI). ${ }^{9}$ We use hedonic indexes which are based on transaction prices for single-family homes, multi-family homes, and condominiums respectively. Similar data for rents are unavailable at the regional level for our sample period. ${ }^{10}$ The average annual increase in house prices from 2001 to 2006 is $1.52 \%$ for single-family homes, $2.06 \%$ for multi-family homes, and $1.43 \%$ for condominiums (weighted by population over the 85 regions). ${ }^{11}$

7 These turnover rates are indicative for select regions based on information from WüEST \& Partner (2004).

8 As consequence, the empirical results that include all 106 regions tend to demonstrate greater instability.

9 There are several providers of regional house prices indexes in Switzerland. The two leading indexes are the IAZI and the Wüest $\&$ Partner index. Both indexes are based on hedonic transaction prices and are calculated on a quarterly basis. Н̈̈скі (2015) uses data based on the Wüest \& Partner price indexes and finds comparable results. A direct comparison between the two indexes would be desirable and is left for future study.

10 A regional rental price index is available from homegate.ch starting only in 2003. Especially for small MS-regions this index however has to be interpreted with caution because calculations are based on a small number of observations.

11 The respective unweighted figures are $1.20 \%$ for single-family homes, $2.08 \%$ for multifamily homes, and $0.99 \%$ for condominiums, suggesting that home prices for larger regions grew 
Data on the number of foreigners grouped by their country of origin are available at the municipality level. Between 2001 and 2006, Switzerland had an overall positive net migration rate of 2.9 per 1000 inhabitants, consistent with the European average of 3.0 per 1000 inhabitants, see MüNZ (2007). For our sample of 85 regions, this number rises to 3.3. Data source is the State Secretariat for Migration (SEM). Further, data on the number of unemployed for each municipality are from the State Secretariat for Economic Affairs (SECO). Last, data on the total resident population and on five socio-economic and regional indicators for each municipality are from the Swiss Statistics Office (BFS).

The socio-economic and regional indicators from the State Secretariat for Economic Affairs are the average municipality size in a region (8 different categories), an indicator capturing the main language spoken in a region (4 categories), an indicator for the economic strength of a region (1 if the region receives fiscal transfers, 0 otherwise), and a socio-cultural indicator capturing the average social status of the population in a region based on their income, education level and professional status (index ranging from 0 to 100). Finally, we also include a variable capturing the typology of a region (14 different categories from agglomeration to rural). Information at the municipality level is weighted by municipality size and aggregated to the regional level.

Table 1 shows descriptive statistics for immigration and house prices for 10 regions with the largest immigrant-to-population ratio and 10 regions with the lowest immigrant-to-population ratio. Despite modest house price inflation and immigration flows at the national level, the statistics show considerable variation at the local level. The first column records the immigrant-to-population ratio for 2006. The unweighted average of the 10 largest immigrant regions is more than three times larger than the unweighted average of the 10 smallest immigrant regions. The second column documents larger immigrant regions in 2006 that have larger populations by a factor of three. The third column displays the aggregate change in immigration between 2001 to 2006 relative to the population from 2001. Again, larger immigrant regions experienced greater immigration flows than did smaller ones. The unweighted averages differ by a factor of 13. The next three columns show the cumulative price change over the sample for single-family homes (sfh), multi-family homes ( $\mathrm{mfh}$ ), and condominiums (con). Larger price changes are observed for larger immigrant regions. Particularly

slightly faster. The fact that new construction investment as a percentage of GDP stagnated at $6 \%$ throughout our sample is a further reflection of the moderate price growth for Swiss homes. Weak persistence is a further implication of the moderate house price inflation. 


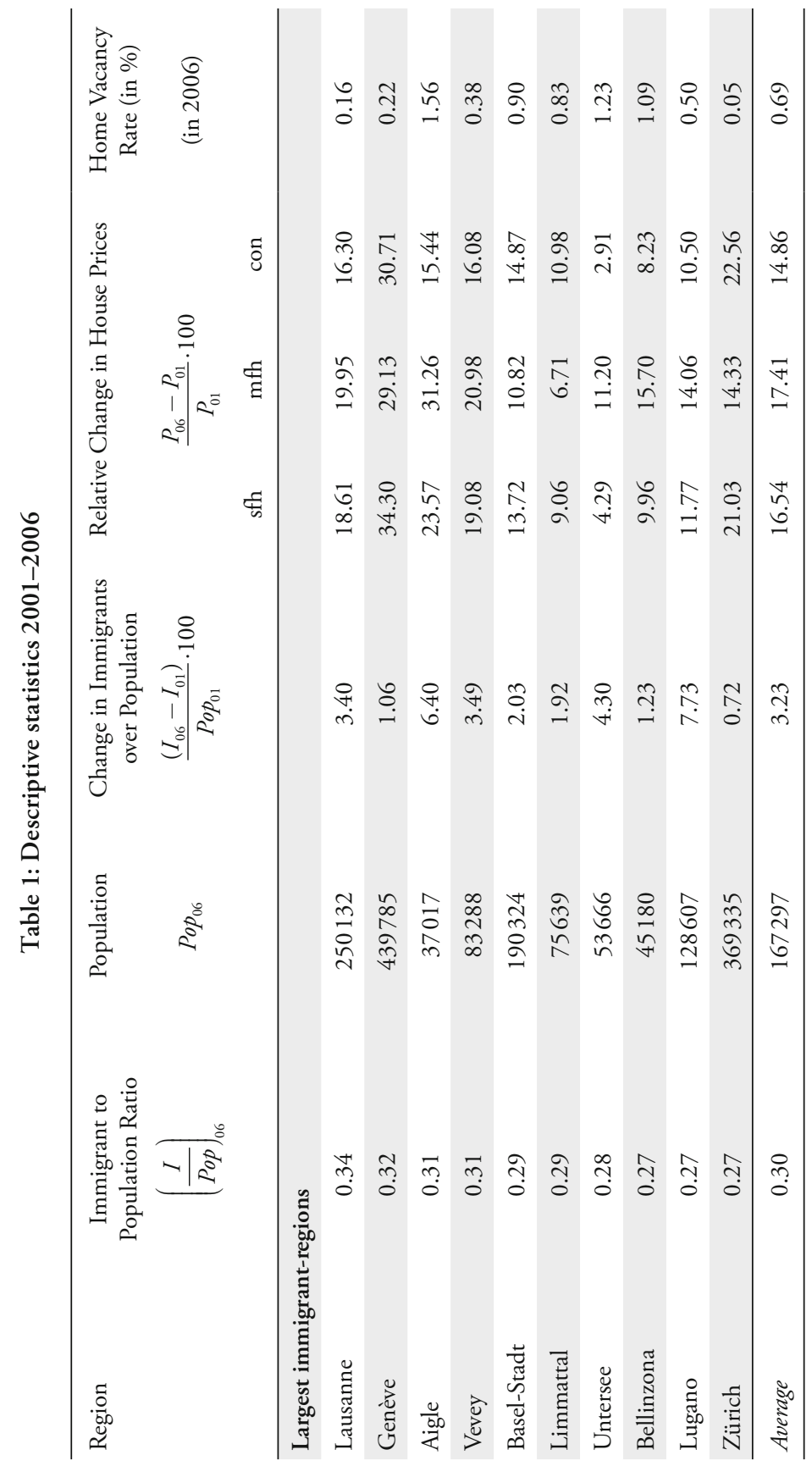




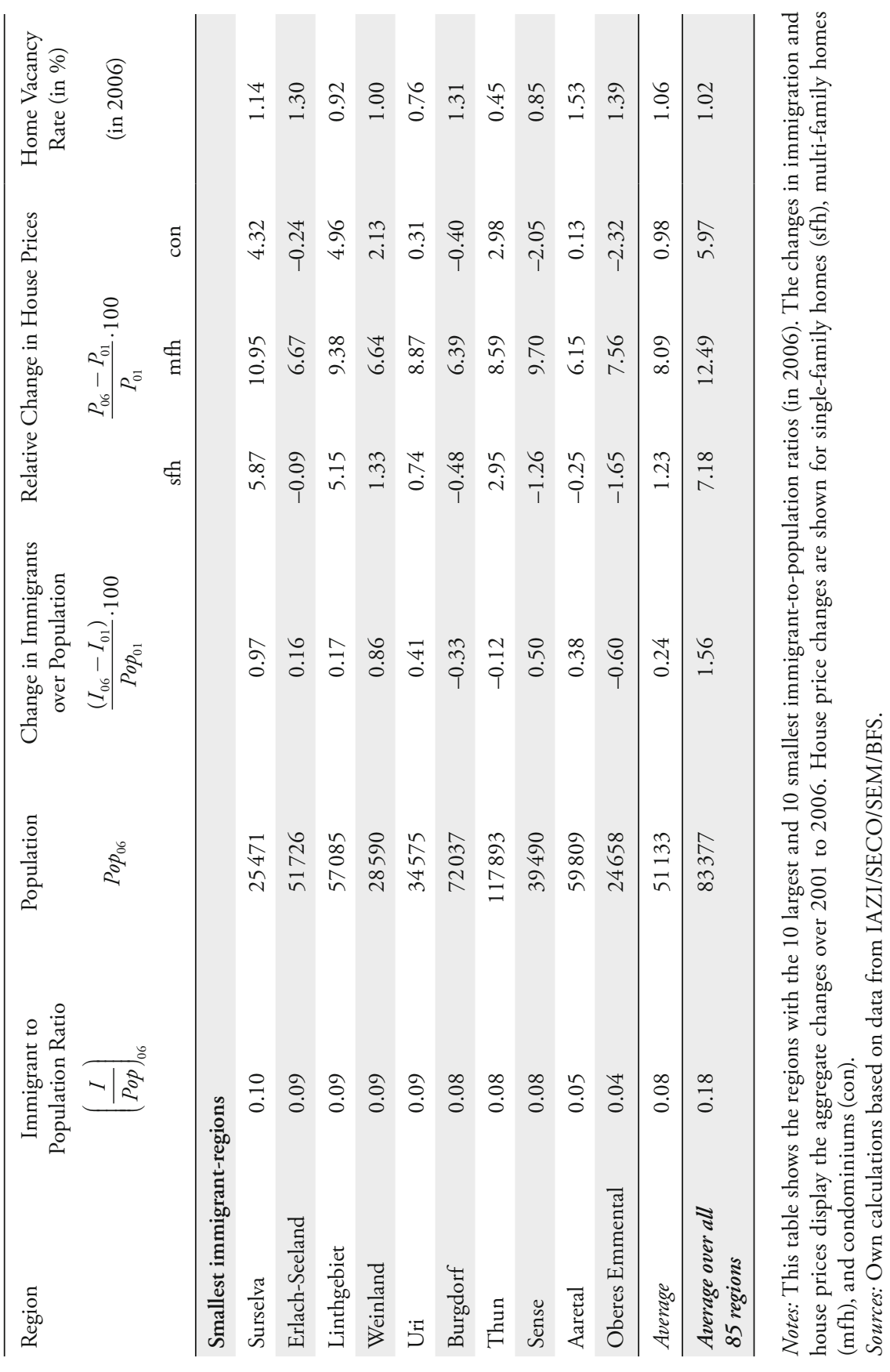


large differences between large and small immigrant regions arise for condominiums and single-family houses. The last column presents vacancy rates for 2006. Again, larger immigrant regions are marked by lower vacancy rates. The differences between the averages for the largest and smallest immigrant regions however are not strikingly large. This evidence suggests that the Swiss house market is tight irrespective of location.

\section{Econometric Specification}

We estimate the effect of immigrant inflows on house prices at the regional level. Our empirical baseline specification follows SAIZ (2007)

$$
\Delta p_{i t}=\mu_{t}+\beta\left(\frac{\Delta I_{i t}}{P O P_{i t-1}}\right)+\gamma_{1} \Delta u_{i t-1}+\gamma_{2} X_{i}+\varepsilon_{i t},
$$

where $\Delta p_{i t}=\ln \left(p_{i t} / \mathrm{p}_{i t-1}\right)$ denotes the annual change in house prices in region $i$ at time $t$. The immigration effect is captured by $\Delta I_{i t} / P O P_{i t-1}$, the immigrant flow relative to the population at $t-1$ for region $i$. Changes in the number of unemployed divided by population is denoted by $\Delta u_{i t-1}$. Further, $\mu_{t}$ are yearly fixed effects and $X_{i}$ is a set of control variables, capturing region-specific characteristics. The shock to house prices in region $i$ at time $t$ is $\varepsilon_{i t}$.

The coefficient of interest, $\beta$, is interpreted as the percentage change of house prices associated with annual inflows of immigrants equal to $1 \%$ of a region's population. Because of the annual frequency of our sample, $\beta$ is interpreted as a short-run estimate in which the supply of housing does not respond immediately to immigration. ${ }^{12}$ In other words, an increase in immigration into a region raises its local population and thereby the demand for housing. The increase in local demand raises prices and results in a positive $\beta$.

This positive effect of immigration on house prices also assumes that natives are not infinitely sensitive to changes in housing costs and that native displacement

12 Gonzalez and Ortega (2013) and Saiz (2007) also work with annual data and interpret $\beta$ as a short-run estimate capturing demand effects. By contrast, the literature that relies on census data such as Greulich et al. (2004) and Ottaviano and Peri (2012) for the United States interpret the results at the decennial frequency as long-run estimates. The latter interpretation assumes that housing supply varies in response to immigration, although the former interpretation does not. 
from the local housing market is not complete. One interpretation for this effect offered by SAIZ (2007) is that immigrants are less sensitive to housing costs, because local immigrant-specific amenities and networks are more important to them.

An empirical shortcoming of the baseline equation (1) is that we do not include a measure of household income for the full sample estimates. This limitation is due to data availability. ${ }^{13}$ The absence of Swiss income means that our estimates for $\beta$ in equation (1) are potentially subject to an omitted variables bias. We however include an index of social economic status that partly makes up for the missing income, because it reflects the average income, education level and professional status of a region's population. Additionally, based on a restricted sample with household income at the regional level we show in a sensitivity analysis that the omitted variables bias linked to income does not influence our empirical results.

Potential measurement problems for our measure of immigrant flows raise concerns regarding the attenuation bias for our estimate of $\beta$, see Aydemir and BorJas (2011). Immigration flow is measured as the annual change in the number of foreign nationals residing in Switzerland. Because the immigration stock varies in response to naturalized citizens and births of foreign nationals, our measure of immigration flow is contaminated. This measurement problem drives the OLS estimate of $\beta$ towards zero. Although at the national level the difference between foreign nationals and the foreign born population is small by international comparisons, it is difficult to determine how large the measurement problem is across regions. ${ }^{14}$

Establishing causality through an exogenous source of fluctuations in immigration inflows represents an additional concern for OLS estimation of $\beta$ in equation (1). Immigration to a local area is likely to be an endogenous event. For example, when controlling for local factors, immigrants may prefer areas where housing costs are increasing more slowly. This sensitivity to rising housing costs biases the OLS estimate of $\beta$ towards zero.

To overcome problems of measurement error and of endogeneity linked to $\Delta I_{i t} / P O P_{i t-1}$, we employ an instrumental variables (IV) strategy based on the

13 Income data at the regional level is available only for the cantons of Basel-City, Zurich and Thurgau for the year 2000. We are therefore unable to construct a measure for income changes at the regional level for the full sample.

14 Swiss record keeping of immigrants follows the "ius sanguinis" concept. In 2006, foreign nationals represented $20.2 \%$, foreign born residents $22.9 \%$ of the total population. See Table 3 in MünZ (2007) for European comparisons. 
settlement patterns of immigrants in previous periods. The idea is to exploit the finding of BARTEL (1989) that immigrants tend to move to regions where many fellow compatriots already live in order to connect to earlier immigrants form the same country of origin. This instrumentation strategy developed by CARD (2001) has been widely applied in the context of housing prices and rents, e. g. by SAIZ (2007) or Ottaviano and Peri (2012) for the United States, Gonzalez and Ortega (2013) for Spain, or Accetturo et al. (2014) for Italy. The instrument is constructed so that it is independent from local contemporary demand factors, which might affect the current settlement choices of immigrants. The instrument, also referred to as the "supply push component", is constructed as follows:

$$
S P_{i t}=\sum_{c} \frac{\lambda_{c i}^{1997} \Delta I_{c t}}{P O P_{i t-1}}, \text { with } \lambda_{c i}^{1997}=\frac{I_{c i}^{1997}}{I_{c}^{1997}} .
$$

The share of immigrants from country $c$ settling in region $i$ in 1997 is denoted by $\lambda_{c i}^{1997} \cdot{ }^{15}$ The variable, $\Delta I_{c t}=I_{c t}-I_{c t-1}$, is the year-to-year change in the national level of immigrants from country $c$. By summing $\lambda_{c i}^{1997} \Delta I_{c t}$ over origin countries, we hope to obtain a predicted measure of total immigrant inflows in region $i$ at time $t$ that is orthogonal to local demand conditions. Finally, the instrument is normalized by the population in region $i$ at $t-1$.

\section{Estimation Results}

In this section, we show that immigration flows are coincident with increases in house prices using price indexes of three different home types. This result is surprising given the low level of house price inflation. We first present baseline estimates based on equation (1) in Tables 2 and 3. Thereafter, we conduct a number of sensitivity checks to determine the robustness of our point estimates for local immigration flows. In particular, we show that income is not an important determinant of house price inflation. This result suggests that our estimates of $\beta$ in the baseline specification do not suffer from omitted variables bias due to the absence of income.

15 Munshi (2003) shows that settlement patterns of previous immigrants determine location choices of arriving immigrants from the same country of origin. We construct the instrument with 11 countries of origin: Austria, France, Germany, Italy, the Netherlands, Portugal, Serbia, Spain, Turkey, and the United Kingdom. 
Table 2: OLS Regressions for the y/y Log-Change in House Prices $\left(\Delta p_{i t}\right)$

\begin{tabular}{lccc|ccc}
\hline & \multicolumn{3}{c|}{ with regional control variables } & \multicolumn{3}{c}{ with regional fixed effects } \\
& sfh & mfh & con & sfh & mfh & con \\
& $(1)$ & $(2)$ & $(3)$ & $(4)$ & $(5)$ & $(6)$ \\
\hline$\Delta I_{i t} / P_{0} p_{i t-1}$ & 0.553 & 0.803 & 0.361 & 0.569 & 0.800 & 0.388 \\
& {$[0.408]$} & {$[0.391]^{* *}$} & {$[0.269]$} & {$[0.272]^{* *}$} & {$[0.238]^{* * *}$} & {$[0.206]^{*}$} \\
& $(0.345)$ & $(0.371)^{* *}$ & $(0.234)$ & $(0.493)$ & $(0.472)^{*}$ & $(0.322)$ \\
$\Delta u_{i t-1}$ & -0.111 & 1.833 & 0.954 & -0.309 & 1.901 & 0.817 \\
& {$[1.144]$} & {$[0.862]^{* *}$} & {$[0.833]$} & {$[1.404]$} & {$[1.224]$} & {$[1.062]$} \\
& $(0.914)$ & $(0.954)^{*}$ & $(0.696)$ & $(1.128)$ & $(0.879)^{* *}$ & $(0.803)$ \\
\hline Year FE & $\mathrm{y}$ & $\mathrm{y}$ & $\mathrm{y}$ & $\mathrm{y}$ & $\mathrm{y}$ & $\mathrm{y}$ \\
Observations & 510 & 510 & 510 & 510 & 510 & 510 \\
Regions & 85 & 85 & 85 & 85 & 85 & 85 \\
$R^{2}$ (within) & 0.56 & 0.88 & 0.32 & 0.58 & 0.89 & 0.27 \\
\hline
\end{tabular}

Notes: This table displays the baseline OLS relation between changes in immigration and the Swiss house price index. The dependent variables are the annual change in the logarithm of the house price indexes, $\Delta p_{i t}$, for single-family homes (sfh), multi-family homes ( $\mathrm{mfh}$ ), and condominiums (con). $\Delta I_{t t} / P_{o p_{i t-1}}$ is the $\mathrm{y} / \mathrm{y}$ change in immigrants relative to the population in region $i$ at time $t-1$. $\Delta u_{i t-1}$ denotes the change in unemployed divided by population in region $i$ and time $t-1$. All estimations include fixed effects by year. Columns 1 to 3 estimate the baseline specification with 5 regional indicators, and columns 4 to 6 account for regional differences by including regional FE. Heteroskedasticity-robust standard errors in parentheses; clustered standard errors (by region) in brackets; ${ }^{*}$ significant at $10 \%$; ${ }^{* *}$ significant at $5 \%$; ${ }^{* * *}$ significant at $1 \%$.

Sources: Own calculations based on data from IAZI/SECO/SEM/BFS.

Table 2 presents OLS regressions for single-family homes, multi-family homes, and condominiums respectively. All regressions are estimated with time fixed effects. Our baseline specification includes a number of control covariates which account for socio-economic differences across regions. The main estimates which include these regional control covariates are reported in columns 1 to 3 . Columns 4 to 6 are estimated using region fixed effects, taking into account observed and unobserved time-invariant and region-specific factors. The coefficients of the regional and time controls are not reported in the tables. Heteroskedasticityrobust standard errors are reported in parentheses, although cluster-robust standard errors accounting for potential serial correlation at the regional level are reported in brackets.

The OLS regressions for the three types of house prices show that the coefficients for immigrant flows lie between 0.361 and 0.800 . These estimates imply 
that an immigrant inflow equal to $1 \%$ of a regions' population is associated with a modest raise in housing prices between $0.3 \%$ and $0.8 \%$, irrespective of the econometric specification. The price effect from immigration is highest for multi-family homes, followed by single-family homes, then condominiums. This ordering is consistent with the average price increases for the three house types and reflects that new immigrants are most likely to rent and thus drive up multifamily home prices most.

Table 3 presents IV regressions for the same specifications shown in Table 2. For all IV specifications, the price effects through immigration are larger than the OLS estimates. This result suggests that the OLS estimates are biased downward due to measurement and endogeneity problems, a finding consistent with Saiz (2007) and Gonzalez and Ortega (2013). The regressions of the baseline specification with regional indicators are displayed in columns 1 to 3 . The coefficient estimates of the immigrant-price effect are significant and range between 1.456 and 3.485, depending on house type. More specifically, an immigration inflow equal to $1 \%$ of an area's population is associated with an increase in multi-family house prices of $3.5 \%$ and $2.7 \%$ for single-family home prices respectively. Similar to the OLS estimation, the IV estimates are largest for multi-family home prices. Again, this might reflect that the demand pressure from new immigrants is likely to be largest for rental apartments which are usually located in multi-family homes. The effect of immigration on single-family homes and condominiums can act through different channels: On the one hand, immigration - especially high-skilled white-collar immigration - could directly drive up single-family home and condominium prices. On the other hand, immigration could induce native displacement which in turn drives prices for single-family homes and condominiums up. Another possible channel is that immigrant flows affect rental prices and this in turn affects house prices through the present value relationship of higher streams of future rents. These are hypotheses that should be investigated further in future work based on both rental and housing prices.

To better understand the price effect from immigration of 2.7 for single-family homes, we calculate the average effect of immigration on house prices. First, we consider the average immigrant flows over the 85 regions from 2001 to 2006. This annual average is $0.33 \%$ of a region's population. The overall immigration effect for single-family houses in our sample is $0.33 \% \times 2.7 \approx 0.99 \%$. This means that almost two-thirds $(0.99 \% / 1.52 \% \approx 0.60)$ of the total price increase is attributed to demand effects of immigration. This average effect from immigration flows is higher for Switzerland than the average estimate of one-third for Spain's boom episode examined by Gonzalez and Ortega (2013). 
Table 3: IV Regressions for the $y / y$ Log-Change in House Prices $\left(\Delta p_{i t}\right)$

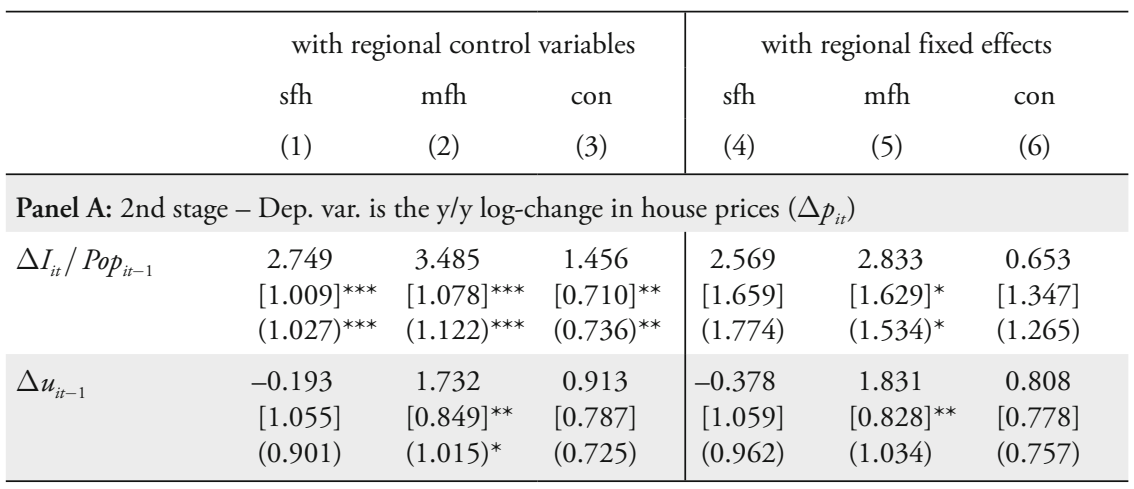

Panel B: 1st stage - Dep. var. is the y/y change of immigrants to population ratio $\Delta I_{i t} / P_{p} p_{i t-1}$

\begin{tabular}{lccc|ccc}
$S P_{i t}$ & 0.856 & 0.856 & 0.856 & 1.132 & 1.132 & 1.132 \\
& {$[0.193]^{* * *}$} & {$[0.193]^{* * *}$} & {$[0.193]^{* * *}$} & {$[0.331]^{* * *}$} & {$[0.331]^{* * *}$} & {$[0.331]^{* * *}$} \\
& $(0.201)^{* * *}$ & $(0.201)^{* * *}$ & $(0.201)^{* * *}$ & $(0.331)^{* * *}$ & $(0.331)^{* * *}$ & $(0.331)^{* * *}$ \\
\hline Year FE & $\mathrm{y}$ & $\mathrm{y}$ & $\mathrm{y}$ & $\mathrm{y}$ & $\mathrm{y}$ & $\mathrm{y}$ \\
Observations & 510 & 510 & 510 & 510 & 510 & 510 \\
Regions & 85 & 85 & 85 & 85 & 85 & 85 \\
$R^{2}$ (1st stage) & 0.15 & 0.15 & 0.15 & 0.09 & 0.09 & 0.09 \\
F-Test (1st stage) & 19.62 & 19.62 & 19.62 & 11.70 & 11.70 & 11.70 \\
\hline
\end{tabular}

Notes: Panel A in this table displays the 2nd stage of the instrumental variables (IV) relations between changes of immigration and the Swiss house price index. The dependent variables are the annual change in the logarithm of the house price indexes, $\Delta p_{i t}$, for single-family homes (sfh), multi-family homes ( $\mathrm{mfh}$ ), and condominiums (con). $\Delta I_{i t} / P o p_{i t-1}$ is the $\mathrm{y} / \mathrm{y}$ change in immigrants relative to the population in region $i$ at time $t-1 . \Delta u_{i t-1}$ denotes the change in unemployed divided by population in region $i$ and time $t-1$. In Panel B the first-stage relation is displayed. The instrument $S P_{i t}$ is the estimated immigrant change, based on the settlement patterns of immigrants in 1997. All estimations include fixed effects by year. Columns 1 to 3 estimate the baseline specification with 5 regional indicators and columns 4 to 6 account for regional differences by including regional FE. Heteroskedasticity-robust standard errors in parentheses; clustered standard errors (by region) in brackets; ${ }^{*}$ significant at $10 \%$; ${ }^{* *}$ significant at $5 \%$; ${ }^{* * *}$ significant at $1 \%$.

Sources: Own calculations based on data from IAZI/SECO/SEM/BFS.

Next in columns 4 to 6 , we present regressions with fixed effects, controlling not only for observed region-specific differences but also taking into account unobserved but time-invariant factors that differ across regions. The coefficient estimates are slightly lower with respect to our preferred specification with regional 
controls in columns 1 to 3 . As expected with fixed effects, the standard errors increase such that only multi-family homes remain significant at the $10 \%$ level.

Panel B of Table 3 shows the first-stage regressions between the endogenous variable $\Delta I_{i t} / P O P_{i t-1}$ and the instrument, $S P_{i t}$ (and the remaining covariates). Our estimate with instruments is 0.856 in the specification with regional controls, 0.861 without regional controls, and 1.132 with fixed effects. Each of these instruments are significant at the $1 \%$ level. The F-tests for the joint significance of the excluded instruments range between 11.70 and 25.93, suggesting that our instruments do not suffer from the criticism of weak instruments.

Next, Table 4 presents several robustness tests for single-family homes with regional controls. Almost all robustness checks show that our baseline estimate of 2.7 is not sensitive to alternative specifications. Column 1 replicates the baseline estimates from Table 3 for comparative purposes. ${ }^{16}$

The next two columns consider the role of income changes, which could effect house prices in a positive manner. In column 2 , we add changes in taxable household income (per capita) for the 85 regions for 2002 to 2006. Column 2 that shows the immigrant effect for $\Delta I_{i t} / P O P_{i t-1}$ rises to 3.245 in the specification with lagged changes in household income. To determine whether income or the smaller sample that excludes 124 observations is responsible for the stronger price effect, column 3 shows the specification without income for the restricted sample. Although income entered significantly in column 2, the regression in column 3 shows an estimate of 3.334 for $\Delta I_{i t} / P O P_{i t-1}$. This evidence suggests that the inclusion of household income does not strongly affect house prices.

As a further sensitivity check, we consider whether the 11 largest regions with a population greater than 150000 influence our estimates. ${ }^{17}$ Column 6 shows that the coefficient estimate for $\Delta I_{i t} / P O P_{i t-1}$ falls to 2.1 in the restricted sample that excludes the 11 largest regions compared to the baseline estimate of 2.7 in the full sample. A $\chi^{2}(6)$ test with a p-value of 0.017 rejects the null that the immigration effect from the sample without large regions is the same as the baseline estimate. We interpret this result to mean that our baseline estimates are driven by large regional dynamics. An explanation for this large regional effect is simply that immigrants are more likely to reside in larger regions because these regions offer better job opportunities and amenities. Indeed, over $40 \%$ of the total immigrants live in the 11 regions with populations larger than 150000 .

16 Corresponding estimates for multi-family home prices and condominium prices are available upon request.

17 The 11 regions are Aarau, Basel-City, Basel-Lower Area, Bern, Geneva, Glattal-Furttal, Lausanne, Luzern, St Gall, Winterthur, and Zurich. 
Table 4: IV Regressions for the $\mathrm{y} / \mathrm{y} \log -$ Change in House Prices $\left(\Delta p_{i t}\right)$

\begin{tabular}{|c|c|c|c|c|}
\hline & $\begin{array}{l}\text { Baseline } \\
\text { (1) }\end{array}$ & $\begin{array}{l}\text { restricted sample } \\
\text { with income } \\
\text { (2) }\end{array}$ & $\begin{array}{l}\text { restricted sample } \\
\text { w/o income } \\
\text { (3) }\end{array}$ & $\begin{array}{l}\text { excl. large } \\
\text { regions } \\
(4)\end{array}$ \\
\hline \multicolumn{5}{|c|}{ Panel A: 2nd stage - Dep. var. is the y/y log-change in house prices $\left(\Delta p_{i t}\right)$} \\
\hline$\Delta I_{i t} / P_{o p}{ }_{i t-1}$ & $\begin{array}{l}2.749 \\
{[1.009]^{* * *}} \\
(1.027)^{* * *}\end{array}$ & $\begin{array}{l}3.245 \\
{[1.095]^{* * *}} \\
(0.928)^{* * *}\end{array}$ & $\begin{array}{l}3.334 \\
{[1.096]^{* * *}} \\
(0.930)^{* * *}\end{array}$ & $\begin{array}{l}2.115 \\
{[0.817]^{* * *}} \\
(0.919)^{* *}\end{array}$ \\
\hline$\Delta u_{i t-1}$ & $\begin{array}{l}-0.193 \\
{[1.055]} \\
(0.901)\end{array}$ & $\begin{array}{c}-0.447 \\
{[0.639]} \\
(0.862)\end{array}$ & $\begin{array}{c}-0.542 \\
{[0.633]} \\
(0.861)\end{array}$ & $\begin{array}{c}1.329 \\
{[3.173]} \\
(2.070)\end{array}$ \\
\hline$\Delta \ln y_{i t-1}$ & & $\begin{array}{l}0.031 \\
{[0.012]^{* * *}} \\
(0.013)^{* *}\end{array}$ & & \\
\hline
\end{tabular}

Panel B: 1st stage - Dep. var. is the y/y change of immigrants to population ratio $\Delta I_{i t} / P_{p} p_{i t-1}$

\begin{tabular}{lcccc}
$S P_{i t}$ & 0.856 & 1.147 & 1.156 & 0.987 \\
& {$[0.193]^{* * *}$} & {$[0.246]^{* * *}$} & {$[0.246]^{* * *}$} & {$[0.181]^{* * *}$} \\
& $(0.201)^{* * *}$ & $(0.172)^{* * *}$ & $(0.171)^{* * *}$ & $(0.215)^{* * *}$ \\
\hline Year FE & $y$ & $y$ & $y$ & $y$ \\
Observations & 510 & 304 & 304 & 444 \\
Regions & 85 & 85 & 85 & 74 \\
$R^{2}$ (1st stage) & 0.17 & 0.26 & 0.25 & 0.16 \\
F-Test (1st stage) & 28.95 & 21.68 & 22.11 & 29.85 \\
\hline
\end{tabular}

Notes: Panel A in this table displays the 2nd stage of the instrumental variables (IV) relations between changes of immigration and the Swiss house price index. The dependent variables are the annual change in the logarithm of the house price indexes, $\Delta p_{i t}$, for single-family homes (sfh), multi-family homes ( $\mathrm{mfh}$ ), and condominiums (con). $\Delta I_{i t} / P_{o p} p_{i t-1}$ is the $\mathrm{y} / \mathrm{y}$ change in immigrants relative to the population in region $i$ at time $t-1 . u_{i t-1}$ denotes the change in unemployed divided by population in region $i$ and time $t-1$ and $\Delta \ln y_{i t-1}$ is the change in the log of per capita income. In Panel B the first-stage relation is displayed. The instrument $S P_{i t}$ is the estimated immigrant change, based on the settlement patterns of immigrants in 1997. All estimations include fixed effects by year. Columns 1 to 3 estimate the baseline specification with 5 regional indicators and columns 4 to 6 account for regional differences by including regional FE. Heteroskedasticityrobust standard errors in parentheses; clustered standard errors (by region) in brackets; * significant at $10 \%$; ${ }^{* *}$ significant at $5 \%$; ${ }^{* *}$ significant at $1 \%$.

Sources: Own calculations based on data from IAZI/SECO/SEM/BFS. 


\section{Conclusions}

The empirical results show that the nexus between immigration and house prices holds even in an environment of low house price inflation and modest immigration flows. An immigration inflow equal to $1 \%$ of an area's population is coincident with an increase in prices for single-family homes of about $2.7 \%$, a result consistent with previous studies. The overall immigration effect for single-family houses captures almost two-thirds of the total price increase. We further show that the push effect of immigrants is strongest when considering multi-family homes. A possible explanation for this could be that new immigrants are more likely to settle in a rental apartment of a multi-family home.

The channels through which immigration affects prices of single-family homes are not fully understood. One possible channel says that prices of all types of homes are affected by new immigrants, because local residents remain in the community but move from rental into condominiums or single-family homes. Another possible channel is that immigrant flows affect rental prices and this in turn affects house prices through the present value relationship of higher streams of future rents. Future work on immigration and housing prices should take into account rental prices to better understand the channels through which immigration affects house prices.

\section{References}

Accetturo, Antonio, Francesco Manaresi, Sauro Mocetti, and Elisabetta Olivieri (2014), "Don't Stand so Close to Me: The Urban Impact of Immigration", Regional Science and Urban Economics, 45, pp. 45-56.

Akbari, Ather H., and Yigit Aydede (2012), "Effects of Immigration on House Prices in Canada", Applied Economics, 44(13), pp. 1645-1658.

Aydemir, Abdurrahman, and George J. Borjas (2011), "Attenuation Bias in Measuring the Wage Impact of Immigration", Journal of Labor Economics, 29(1), pp. 69-113.

Bartel, Ann P. (1989), "Where Do the New U.S. Immigrants Live?", Journal of Labor Economics, 7(4), pp.371-391.

Basten, Christoph, and Cathérine Koch (2015a), "Higher Bank Capital Requirements and Mortgage Pricing: Evidence from the Countercyclical Capital Buffer (CCB)", BIS Working Papers No. 511, Bank of International Settlements. 
Basten, Christoph, and Cathérine Koch (2015b), "The Causal Effect of House Prices on Mortgage Demand and Mortgage Supply: Evidence from Switzerland", Journal of Housing Economics, 30, pp. 1-22.

Basten, Christoph, and Michael Siegenthaler (2013), "Do Immigrants

Take or Create Residents' Jobs? Quasi-Experimental Evidence from Switzerland", KOF Working Papers, ETH Zurich.

Borjas, George J. (2003), "The Labor Demand Curve is Downward Sloping:

Reexamining the Impact of Immigration on the Labor Market", Quarterly Journal of Economics, 118(4), pp. 1335-1374.

Borjas, George J. (2006), "Native Internal Migration and the Labor Market Impact of Immigration", Journal of Human Resources, 41(2), pp. 221-258.

Borowiecki, Karol J. (2012), "Dynamics of a Protected Housing Market: The Case of Switzerland”, Urban Studies, 49(14), pp.3195-3210.

Card, David (2001), "Immigrant Inflows, Native Outflows, and the Local Labor Market Impacts of Higher Immigration", Journal of Labor Economics, 19(1), pp. 22-64.

Drechsel, Dirk (2015), "Housing Cycles in Switzerland: A Time-Varying Approach", KOF Working Paper, ETH Zurich.

Fischer, Andreas M. (2012), "Immigrant Language Barriers and House Prices", Regional Science and Urban Economics, 42(3), pp.389-395.

Fischer, Andreas M. (2014), "Immigration and Large Banknotes", Macroeconomic Dynamics, 18(04), pp. 899-919.

Glitz, Albrecht (2012), "The Labor Market Impact of Immigration: A QuasiExperiment Exploiting Immigrant Location Rules in Germany”, Journal of Labor Economics, 30(1), pp. 175-213.

Gobillon, Laurent, and Matthieu Solignac (2016), "The Access of Immigrants to the Homeownership Market”, Tech. Rep. January 16, 2016.

Gonzalez, Libertad and Francesc Ortega (2013), "Immigration and Housing Booms: Evidence from Spain”, Journal of Regional Science, 53(1), pp. 37-59. Graf, Silvio, Armin Jans, and Daniel Sager (2007), „Personenfreizügigkeit und Wohnungsmarkt", Studie im Auftrag des Bundesamtes für Wohnungwesen, Zürcher Hochschule Winterthur.

Greulich, Erica, John M. Quigley, Steven Raphael, Joseph Tracy, and Guillermina Jasso (2004), "The Anatomy of Rent Burdens: Immigration, Growth, and Rental Housing”, Brookings-Wharton Papers on Urban Affairs, pp. 149-205.

Guin, Benjamin S., and Martin Brown (2015), "Individual Mortgage Choice and Aggregate Mortgage Risk-Evidence from Switzerland", Swiss Journal of Economics and Statistics, 151(2), pp.3-37. 
Häcki, Daniela (2015), „Einwanderung und der Schweizer Immobilienmarkt“, Master thesis, University of Lucerne.

Hunt, Jennifer, and Marjolaine Gauthier-Loiselle (2010), "How Much Does Immigration Boost Innovation?", American Economic Journal: Macroeconomics, 2(2), pp.31-56.

Mack, Adrienne, and Enrique Martinez-Garcia (2011), "A Crosscountry Quarterly Database of Real House Prices: A Methodological Note”, Globalization and Monetary Policy Institute Working Paper No. 99, Federal Reserve Bank of Dallas.

Munshi, Kaivan (2003), "Networks in the Modern Economy: Mexican Migrants in the US Labor Market", Quarterly Journal of Economics, 188(2), pp. 549-599.

Münz, RaIner (2007), "Migration, Labor Markets, and Integration of Migrants: An Overview for Europe", HWWI Policy Paper, Hamburgisches WeltWirtschafts Institut.

Orrenius, Pia M., and Madeline Zavodny (2007), "Does Immigration affect wages? A look at Occupation-Level Evidence”, Labour, 14(5), pp.757-773.

Ottaviano, Gianmarco I.P. and Giovanni Peri (2012), The Effects of Immigration on US Wages and Rents: A General Equilibrium Approach, Edward Elgar Publishing Limited.

SAIZ, A (2007), "Immigration and Housing Rents in American Cities", Journal of Urban Economics, 61(2), pp.345-371.

Stalder, Peter (2003), „Entkoppelung der Mieten vom Hypozins: Implikationen der Mietrechtsrevision für die Geldpolitik“, SNB Quartalsheft, 3, pp. 44-57.

Steiner, Elizabeth (2010), "Estimating a Stock-Flow Model for the Swiss Housing Market", Swiss Journal of Economics and Statistics, 146(3), pp. 601-627.

Stillman, Steven, and David C Maré (2008), "Housing Markets and Migration: Evidence from New Zealand”, Motu Working Paper 08-06, Motu Economic and Public Policy Research.

Werczberger, Elia (1997), "Home Ownership and Rent Control in Switzerland”, Housing Studies, 12(3), pp. 337-353.

Wüest \& Partner (2004), „Analysen und Prognosen Fokus Wohnungsmarkt“, Immo-Monitoring. 